UDC 629.7.067(045)

\author{
${ }^{1}$ Sergii Polishchuk, Assoc. Prof. \\ ${ }^{2}$ Yuriy Chynchenko, Assoc. Prof. \\ ${ }^{3}$ Fedor Shishkov, student
}

\title{
AVIATION ACCIDENTS AND INCIDENTS IN USA DURING 23rd SOLAR CYCLE
}

\author{
National Aviation University \\ ${ }^{1}$ E-mail: stp@nau.edu.ua \\ ${ }^{2}$ E-mail: jdestiny@ukr.net \\ ${ }^{3}$ E-mail: zloon@mail.ua
}

\begin{abstract}
The influence of space weather phenomenon on aviation safety is considered. The correlation between space weather parameters, such as Ap-index, Wolf' number and amount of accidents and occurrences in the World and USA is calculated. The main periods of year that characterize the maximum number of accidents and occurrences are determined.
\end{abstract}

Keywords: aviation accident, flux of high-energy particulars, geomagnetic storm, planetary index of Earth geomagnetic field disturbance, solar flare radio blackouts, solar radiation storm, space weather, Wolf's numbers.

\section{Introduction}

Space weather (SW) refers to the conditions on the Sun and in the solar wind, magnetosphere, ionosphere, and thermosphere that can influence the performance and reliability of space-borne and ground-based technological systems can endanger human life or health (OFCM, 2000 - National Space Weather Program).

The radio communication, satellite navigation, radars, manned space flight, electric power transmission, and air transport show vulnerabilities to solar eruptions, and hence the different procedures to minimize SW impact are devised.

The topicality of SW by the aviation community became even sharper with the use of the northern polar routes and increasing of satellite navigation at the end of the 20th century. Galactic Cosmic Rays, Coronal Mass Ejections, Solar Proton Events, solar flare radio blackouts, radiation storms, geomagnetic storms, and ionospheric storms are some of the terms that became familiar to the aviation industry.

\section{Problem analysis}

SW causes the next negative effects in aviation.

Solar Flare Radio Blackout: disturbances of the ionosphere caused by X-ray emissions from the Sun. High frequency (HF) radio degradation or blackouts are possible at middle and low latitudes.
Solar Radiation Storm: elevated levels of radiation that occur when the numbers of energetic particles increase. Typical effects from solar radiation storms include degradation of satellite tracking and power systems, radiation hazards for humans in flight at high altitudes or high latitudes. HF radio blackouts at high latitudes and induced positional errors with GPS are also possible.

Geomagnetic Storm: disturbances in the geomagnetic field caused by gusts in the solar wind that blows by Earth. Typical effects from geomagnetic storms include degradation of HF radio transmissions, satellite navigation degradation, and disruption of low frequency radio navigation systems. Geomagnetic storms can also disrupt electrical power grids, Air Traffic Controller (ATC) facilities and other national air space components which are susceptible to these power outages.

The solar activity, and SW, as consequence is cyclically changed during $12-14$ years. The last but one 23-solar cycle (1996-2009) was rather ordinary and there have been a few periods of intense SW activity, but a dramatic burst of activity on the Sun was in October/November 2003 (fig. 1).

This period had everything such as: very large sunspot of regions; intense solar flares; particle events; and a huge geomagnetic disturbance. A summary of these effects are shown in tab. 1 [1]. 


\section{Table 1. SW impact on the ground and near-Earth space environment}

\begin{tabular}{|c|c|}
\hline $\begin{array}{l}\text { HF Radio } \\
\text { Systems }\end{array}$ & $\begin{array}{l}\text { Disruptions were reported to HF communications in Australia. } \\
\text { During the X10 flare, an HF fadeout combined with an ionospheric storm to degrade HF } \\
\text { communications in eastern Australia, and across to New Zealand. } \\
\text { HF communications used by aircraft in the northern hemisphere were disrupted. Communications } \\
\text { between aircraft and ground stations were re-routed in some instances to deal with this activity. }\end{array}$ \\
\hline Aurora & $\begin{array}{l}\text { Many reports of aurora were received. } \\
\text { The northern-most point from which auroral observations were reported in Australia was the } \\
\text { Siding Springs Observatory, near Coonabarabran, NSW. } \\
\text { Reports of aurora were received from as far south as Texas in the northern hemisphere. }\end{array}$ \\
\hline Satellites & $\begin{array}{l}\text { The Japanese Kodama satellite was temporarily shut down and may have suffered permanent } \\
\text { damage. } \\
\text { Routine control operations for many satellites were made more difficult. } \\
\text { Within Australia, degraded satellite communications were reported over both Indian and Pacific } \\
\text { Ocean links. } \\
\text { Magnetometer data from the Australian research satellite FEDSAT suggests that its attitude } \\
\text { control was affected during the initial part of the October } 28 / 29 \text { geomagnetic storm. }\end{array}$ \\
\hline GPS system & $\begin{array}{l}\text { For } 15 \text { and } 11 \text {-hour periods in Oct } 2003 \text {, the ionosphere was so disturbed that the vertical error } \\
\text { limit, as defined by the FAA to be no more that } 50 \text { meters, was exceeded. }\end{array}$ \\
\hline $\begin{array}{l}\text { International } \\
\text { Space Station }\end{array}$ & $\begin{array}{l}\text { Crew on the International Space Station ensured that they were protected from enhanced } \\
\text { radiation levels by moving to the aft end of the Service Module as needed. } \\
\text { An hour-long power outage that affected } 20,000 \text { houses in Sweden's southern city of Malmoe } \\
\text { was probably due a geomagnetic storm caused by the solar activity. }\end{array}$ \\
\hline Power Systems & $\begin{array}{l}\text { Power grids in the northern USA and Canada limited the amount of electricity they produced to } \\
\text { deal with induced currents in their transmission grids. }\end{array}$ \\
\hline
\end{tabular}

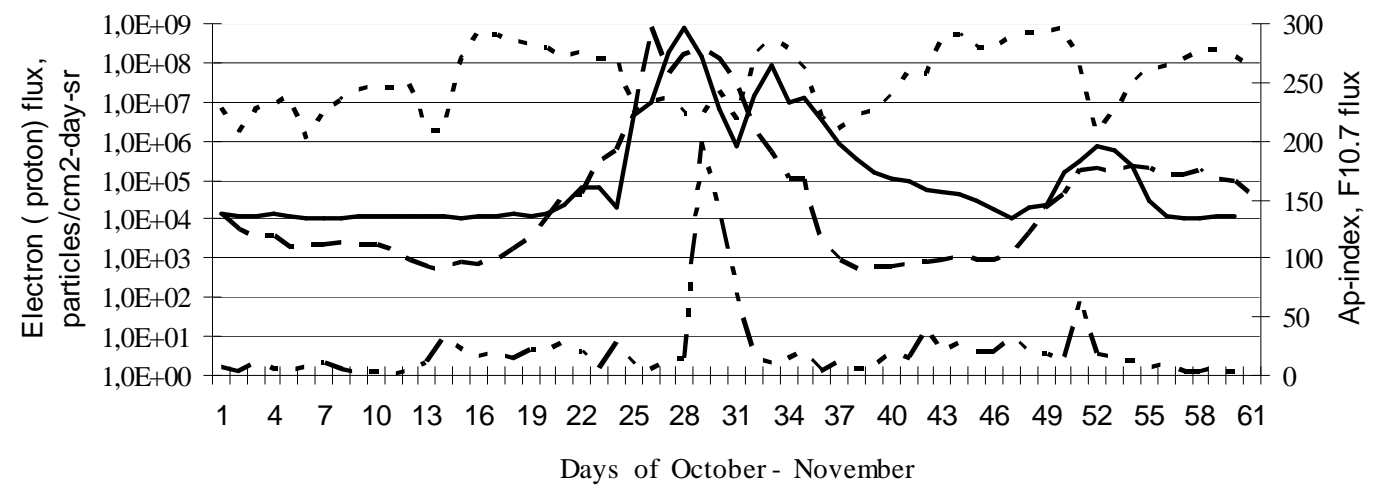

Proron flux, E >10MeV; - - - - Electron flux, E>0.6 MeV; — - Flux $10.7 \mathrm{~cm}$; — - - Ap-index

Fig. 1. Evaluation of SW-parameters in October/November 2003

\section{Purpose of research}

It's known fact that the electronic components of aircraft electronic systems are susceptible to damage from the highly ionizing interactions of cosmic rays, solar particles and the secondary particles generated in the atmosphere. The phenomenon has been observed both on the ground and at the aircraft altitudes [2].

The researches also showed that the intensity of Earth geomagnetic field influences on health and cybernetic possibility of human-operator [3]. 
After consideration of facts listed above the reasonable question appears: Could the SW influence on the initiation of aviation incidents or accidents? And which of SW-parameters can be used for prognostication of aviation safety?

\section{Effect of SW on aviation safety}

First of all, the number of aviation accidents and Wolf' numbers in the World during 1944-2009 were accumulated. The time diagram of these events is shown in fig. 2.

Total correlation coefficient between the number of accidents and solar activity equals to 0.281 , and partial correlation coefficients for six solar cycles are selected in tab. 2.

Geographical regions where in 1944-2009 accidents and incidents (A\&I) had more than 40 events per year were selected on the next step fig. 3 [4].
On the fig. 3 we can see the maximum number of A\&I happened in the USA. And it's also known fact that the USA has the best SW monitoring system in the World. Therefore, with the goal of statistical confidence increasing, for the further analysis, only the number of aviation A\&I in the USA [5] and data of SW states [6] were used.

After SW-data handling (such as value of X-ray, proton and electron fluxes, indices of Earth geomagnetic state) were defined. The maximum correlation between estimated Ap-indices and the number of A\&I during 23-solar cycle is occurred and equals to 0.597 . The timing diagram of this process and numerical data of A\&I are given in fig. 4 and tab. 3 correspondingly.

Graphical representation of A\&I during 1996-2009 and 2003 years are shown in fig. 5.

Table 2. Partial correlation coefficients in 18 - 23 solar cycles

\begin{tabular}{|c|c|c|c|c|c|c|c|}
\hline \multirow{2}{*}{ Period, years } & \multicolumn{2}{|c|}{ Minimum } & \multicolumn{2}{c|}{ Maximum } & \multicolumn{2}{c|}{ Average } & \multirow{2}{*}{$\begin{array}{c}\text { Correlation } \\
\text { coefficient }\end{array}$} \\
\cline { 2 - 7 } & Accident & Wolf & Accident & Wolf & Accident & Wolf & 0,661 \\
\hline $1944-1954$ & 14 & 4 & 56 & 152 & 39 & 69 & 0,018 \\
\hline $1954-1964$ & 36 & 10 & 57 & 190 & 44 & 96 & 0,463 \\
\hline $1964-1976$ & 44 & 13 & 66 & 106 & 54 & 59 & 0,265 \\
\hline $1976-1986$ & 30 & 13 & 62 & 155 & 41 & 83 & 0,020 \\
\hline $1986-1996$ & 35 & 9 & 55 & 158 & 47 & 78 & 0,260 \\
\hline $1996-2009$ & 23 & 3 & 41 & 120 & 31 & 52 & 0,281 \\
\hline
\end{tabular}

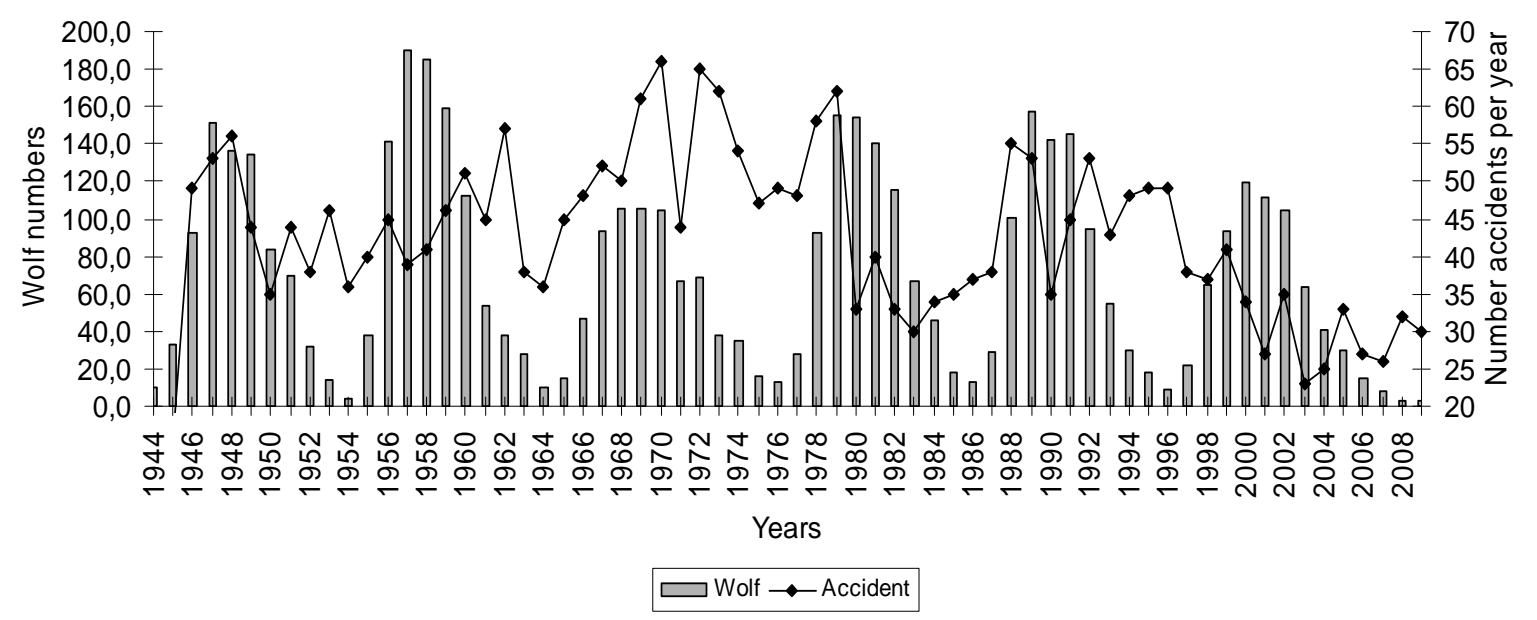

Fig. 2. Evaluation of aviation accidents in $18-23$ solar cycles 
Table 3. Aviation A\&O in USA during 23 solar cycle

\begin{tabular}{|c|c|c|c|c|c|c|c|c|c|c|c|c|c|}
\hline Year & $\begin{array}{l}\stackrel{\vec{\Xi}}{\Xi} \\
\stackrel{\Xi}{\Xi}\end{array}$ & $\begin{array}{l}\vec{E} \\
\vec{E} \\
\frac{0}{0} \\
\text { I. }\end{array}$ & $\begin{array}{l}\frac{\pi}{0} \\
\stackrel{0}{\pi}\end{array}$ & $\overline{\bar{z}}$ & $\stackrel{\overparen{\Xi}}{\Sigma}$ & $\stackrel{\Xi}{\Xi}$ & $\stackrel{\gtrsim}{\Xi}$ & 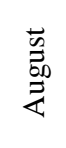 & 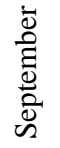 & $\begin{array}{l}\dot{0} \\
\stackrel{0}{0} \\
\stackrel{0}{0} \\
0\end{array}$ & $\begin{array}{l}\dot{\bar{D}} \\
\text { है } \\
\overline{0} \\
\text { z } \\
\text { Z }\end{array}$ & 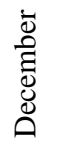 & Total A\&I per year \\
\hline 1996 & 4 & 2 & 0 & 0 & 4 & 3 & 4 & 1 & 2 & 3 & 3 & 3 & 29 \\
\hline 1997 & 5 & 2 & 4 & 2 & 4 & 2 & 3 & 4 & 3 & 2 & 2 & 0 & 33 \\
\hline 1998 & 6 & 6 & 1 & 3 & 3 & 0 & 1 & 3 & 3 & 4 & 2 & 1 & 33 \\
\hline 1999 & 0 & 3 & 1 & 6 & 0 & 1 & 0 & 5 & 2 & 2 & 1 & 6 & 27 \\
\hline 2000 & 3 & 1 & 5 & 1 & 2 & 2 & 3 & 1 & 2 & 2 & 2 & 3 & 27 \\
\hline 2001 & 5 & 1 & 7 & 3 & 3 & 1 & 1 & 4 & 7 & 2 & 2 & 6 & 42 \\
\hline 2002 & 2 & 5 & 2 & 0 & 5 & 2 & 4 & 3 & 1 & 3 & 2 & 7 & 36 \\
\hline 2003 & 9 & 0 & 7 & 7 & 2 & 5 & 2 & 3 & 3 & 1 & 4 & 6 & 49 \\
\hline 2004 & 1 & 1 & 3 & 3 & 1 & 0 & 1 & 6 & 4 & 5 & 3 & 5 & 33 \\
\hline 2005 & 3 & 2 & 2 & 1 & 5 & 4 & 3 & 1 & 5 & 11 & 4 & 5 & 46 \\
\hline 2006 & 3 & 5 & 4 & 1 & 0 & 6 & 7 & 4 & 0 & 1 & 2 & 2 & 35 \\
\hline 2007 & 6 & 3 & 3 & 1 & 2 & 4 & 1 & 2 & 6 & 5 & 0 & 5 & 38 \\
\hline 2008 & 2 & 5 & 1 & 0 & 5 & 5 & 5 & 1 & 3 & 0 & 1 & 2 & 30 \\
\hline 2009 & 5 & 3 & 0 & 1 & 2 & 0 & 1 & 0 & 2 & 2 & 1 & 1 & 18 \\
\hline 2010 & 6 & 9 & 1 & 1 & 1 & 2 & 2 & 0 & 0 & 1 & 1 & 0 & 24 \\
\hline Sum/year & 60 & 48 & 41 & 30 & 39 & 37 & 38 & 38 & 43 & 44 & 30 & 52 & 500 \\
\hline
\end{tabular}

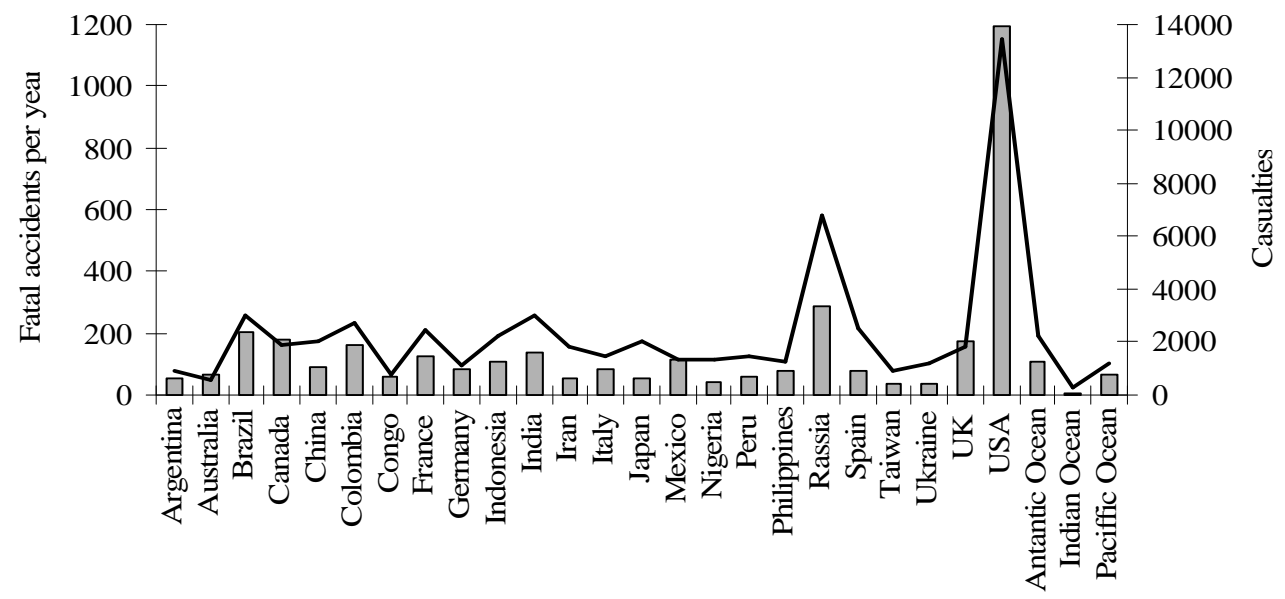

$\square$ Accidents —Casualties

Fig. 3. Geographical regions of A\&I

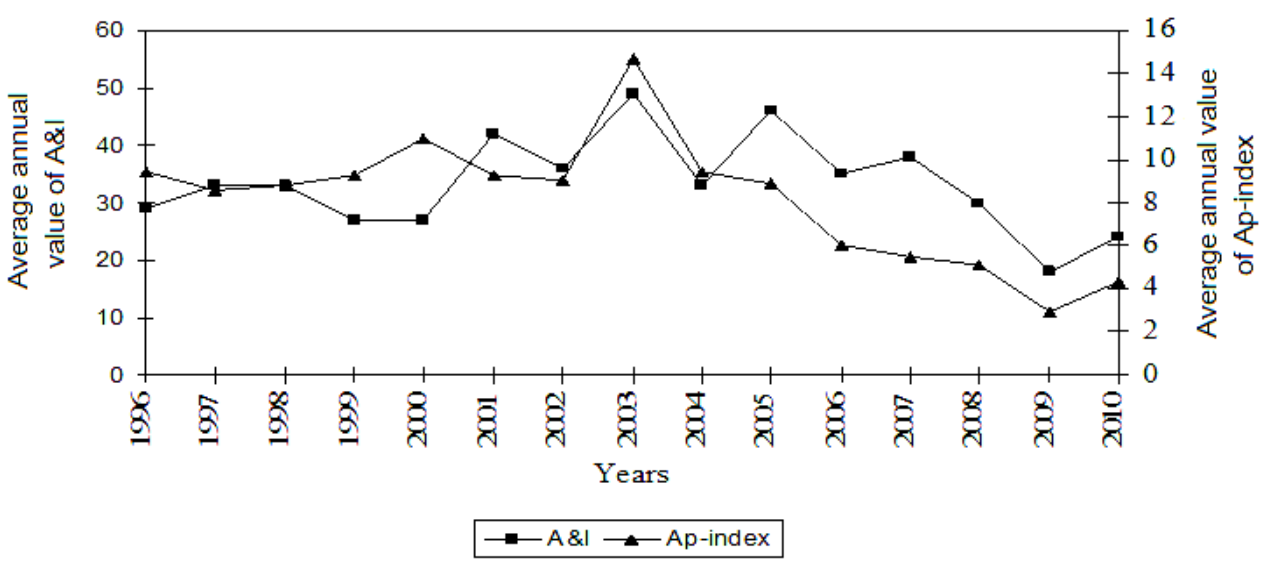

Fig. 4. Evaluation of SW-parameters and A\&O 


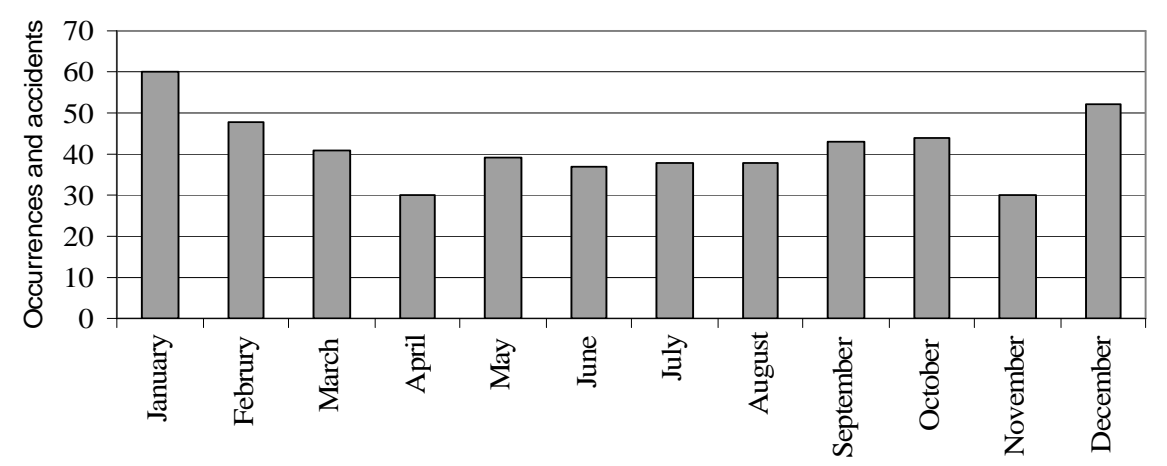

$a$

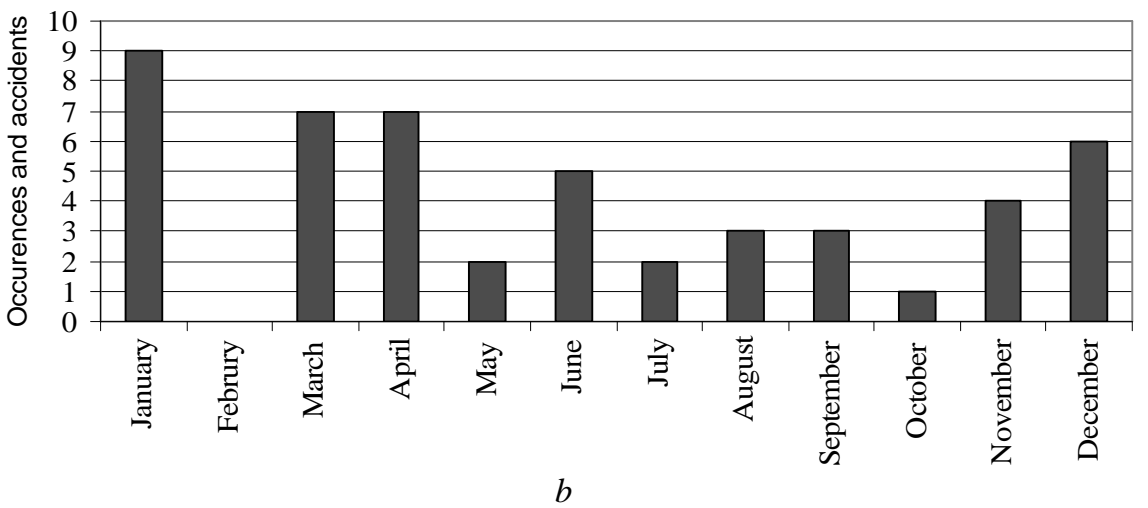

Fig. 5. A\&I per month in the USA: $a-1996-2009$; $b-2003$

\section{Conclusions}

State of solar activity can substantially influence on aviation A\&I: correlation coefficient between Wolf's numbers and number of accidents during 1944-2009 is equal to 0.281; between Ap-index and number A\&I during 23-solar cycle is equal to 0.597.

Maximum average number of A\&I during 23-solar cycle was in 2003 and is equal to 49 , i.e. it had the accurate coincidence with year of the geomagnetic disturbance maxima.

For prognostication of aviation A\&I the Apindex is better SW-parameter than the Wolf's number.

Largest average number of aviation $\mathrm{A} \& \mathrm{O}$ in the USA during 1996-2009 was selected in December and January.

\section{References}

1. A Remarkable Period of Space Weather October-November 2003. Available from Internet: <http:// www.ips.gov.au>.
2. Johansson, K.; Dyreklev, P.; Granbom, B. Space Weather Effects on Aircraft Electronics. Second workshop on AI Applications in SolarTerrestrial Physics in Lund, July 29-31, 1997.

3. Сидякин, В.Г.; Темурьяни, Н.А.; Макеев, В.Б.; Владимирський, Б.М. Космическая экология. - Київ: Наукова думка, 1985.-176 с.

[Sidiakin, V.G.; Temuriants, N.A.; Makeev, V.B.; Vladimirovski, B.M. 1985. Space ecology. Kiev. Naukova dumka. 176 p.] (in Russian).

4. Поліщук, C.T. Оцінювання впливу сонячної активності на можливість виникнення авіаційних катастроф у 1944 - 2009 рр. //Вісник НАУ. 2010.- № 2(43). - C. 58-61.

[Polishchuk, S.T. 2010. Valuation of solar activity impact on possibility of aviation accidents appearance in 1944-2009 years. - Proceedings of the NAU. N 2 (43): 58-61.] (in Ukrainian).

5. Statistic of aviation accident. Available from Internet: <http://www.aviation-safety.net/database/ country $>$.

6. Statistic of space weather parameters. Available from Internet: <http://www.swpc.noaa. gov/data/index.html>. 